\title{
Hiring Disable People to Avoid Staff Turnover and Enhance Sustainability of Production
}

\author{
Tomasz Chajduga and Manuela Ingaldi *ib \\ Faculty of Management, Czestochowa University of Technology, al. Armii Krajowej 19b, \\ 42-200 Czestochowa, Poland; tomasz.chajduga@pcz.pl \\ * Correspondence: manuela.ingaldi@wz.pcz.pl; Tel.: +48-34-32-50-426
}

Citation: Chajduga, T.; Ingaldi, M. Hiring Disable People to Avoid Staff Turnover and Enhance Sustainability of Production. Sustainability 2021, 13, 10577. https://doi.org/10.3390/ su131910577

Academic Editor: Giuseppe Battaglia

Received: 6 August 2021

Accepted: 21 September 2021

Published: 24 September 2021

Publisher's Note: MDPI stays neutral with regard to jurisdictional claims in published maps and institutional affiliations.

Copyright: (c) 2021 by the authors. Licensee MDPI, Basel, Switzerland. This article is an open access article distributed under the terms and conditions of the Creative Commons Attribution (CC BY) license (https:// creativecommons.org/licenses/by/ $4.0 /)$.

\begin{abstract}
Companies struggle with maintaining staff turnover at a low and sustainable level. Hiring a new employee means costs for the company, such as recruitment, medical examinations, and training, etc. In addition, new employees must learn to perform their tasks properly and quickly, which can take up to several months. Disabled employees change jobs less frequently due to the fact that it is difficult for them to find a new one. For employers, such an employee, if they have the same skills as a fully functional employee, can therefore be very valuable, for example, in relation to the reduction of costs associated with frequent employment of new employees. In addition, employing people with disabilities also brings social benefits related to counteracting social exclusion and the possibility of independent living by such people. The human factor is an element that greatly influences sustainable production. The objective of the research was to verify the potential of hiring disabled employees in order to reduce staff turnover. In other words, the analysis has been designed to understand if hiring disabled staff, making expenditures to prepare the workplace and training for them could be potentially efficient in terms of obtaining a higher level of sustainability of the employment in the company. The research has the form of direct (in-depth) interviews in the case of representatives of the companies involved, and a paper questionnaire for the disabled subjects (employees). It took place from September to December 2020 and was the basis for the statistical hypothesis testing. The conducted research was based on a statistical U Mann-Whitney test and fi Yule index calculation. The results showed that people with disabilities remain employed by the same employer longer in comparison to "able-bodied" employees, meaning it may be worthwhile to make extra expenditures to hire disabled persons who could become loyal employees for years. Moreover, it has been statistically proven that the key factor influencing the attractiveness of a given job for a disabled person depends on the type of disability they have.
\end{abstract}

Keywords: sustainability; sustainable production; sustainability of the employment; hiring disabled persons; avoiding employee turnover

\section{Introduction}

\subsection{Sustainable Production}

In the world of literature, there is a discussion about the limitations of the ability of ecosystems to maintain the current level of consumption and production in various types of sectors [1-4]. This discussion is part of the sustainable production concept. Global environmental problems result from over-consumption and unsustainable production. These problems have lead to the appearance of the concept of sustainable production at the United Nations Conference on Environment and Development in 1992 and are closely related to the concept of sustainable development [5].

Sustainable production is about developing various items that can use minimal resources, produce minimum waste and be safer for society at a reasonable cost. According to Hashim et al., the concept of sustainable production basically consists of three elements: (1) selecting the appropriate means of assessing the sustainability of production, 
(2) accurately identifying poor areas, and (3) adaptation to improve the sustainability of production [6]. Frameworks and approaches for sustainable development in relation to production are generally aimed at developing and implementing sustainable development strategies, sustainable business models, design and innovation capabilities, performance improvement and evaluation, and decision-making tools, etc. [7].

Sustainable production has a production and upstream perspective, searching opportunities to alter production processes and related activities in a more sustainable direction, sustainable consumption is directed to how and why goods and services are demanded, used, and consumed [8]. The sustainable production concept has been developed to align industrial sustainability with the global challenges of sustainable development [9]. This initiative, according to Glavič [10], should include:

- resource efficiency (raw materials, energy, and water);

- clean energy and cleaner production;

- low emissions and climate-friendly solutions;

- responsible agriculture;

- chemical leasing;

- corporate social responsibility;

- $\quad$ stakeholder engagement.

There are other elements of sustainable production to be found in various scientific papers. Among the most important mentioned are using fewer resources and energy, producing less pollution or waste, increasing economic viability, employment optimization and elimination of unnecessary employee turnover, increasing the safety of employees, communities and customers, but also increasing the satisfaction of both employees and customers. To achieve the assumptions of sustainable production, various methods, philosophies, and tools can be used that are widely described in the literature, including lean methodology [11], quality control [12-14], value stream mapping (VSM) [15], proper machines and their maintenance management [16,17], and the use of renewable energy source [18]. It is also worth looking at the product life cycle - it is possible to reuse the materials contained therein, which should positively impact the natural environment and waste minimalization, thereby taking into account the assumptions of the circular economy [19].

An important aspect that influences whether a given production can be considered sustainable is the quality of the products. Low-quality products result in the need for additional operations aimed at repairing or scrapping the poor product [20]. It is also related to the low satisfaction of customers, who decide which products to use and from which enterprise [21,22]. High customer satisfaction is directly proportional to the enterprise's profits, and thus, determines its existence on the market.

Sustainable production can be implemented with a positive effect, mainly in enterprises with an appropriate organizational culture [23]. This culture influences the appropriate behavior of employees, who are the most important resource of any enterprise. It is employees who have the greatest influence on how individual resources will be used, what quality products will be made, etc. If the enterprise does not employ appropriate employees, it does not matter whether it uses the latest technologies, technical equipment, or has adequate financial resources, as it is likely to have difficulties in functioning efficiently [24]. A well-built and well-functioning organizational culture requires appropriate behavior and reaction from employees, makes the employees feel part of the enterprise, and therefore encourages them to try to do their best work. In turn, this results in lower production losses, high-quality products, higher profit for the enterprise, and new investment opportunities, which may further create new jobs, and increase the enterprise's production, etc.

\subsection{Human Factor in Sustainable Production}

The authors noted that, unfortunately, in the available literature on sustainable production, the human factor is the least studied and analyzed topic. It is important from the point of view of two areas of sustainable development. When it comes to the economic area, an employee with appropriate qualifications, who perform their work conscientiously, 
has a positive effect on the enterprise's profit. They help in the production of high-quality products, makes sure that the individual resources of the enterprise are used in the most economical way, and takes care of the safety of themself and other employees, etc. From the point of view of the social area, employing local residents allows to reduce unemployment on the market, but also allows to maintain an adequate standard of living for both the employees and their family, and in consequence, it also means the potential elimination of poverty.

However, there has been a significant problem when it comes to employees. In many European markets, there is a lack of specialists, and they are often sought across many European countries and also on other continents. It is related not only to the turnover of employees between countries and continents. Moreover, young people more often choose general education schools, and do not pay attention to acquiring a specific profession. In the last few years, due to the opening of the labor market of the European Union to new members, employees from Eastern European countries have entered the markets of Western Europe, and so, currently, there is a large influx of employees from non-EU countries and Asia. However, hiring foreigners may cause some additional problems.

Very often, such employees may not understand English well, not to mention the local language, so that language barriers can appear. Nevertheless, such an employee must be properly trained and prepared for work, which is often difficult where language barriers occur. Many employees have diplomas proving their education or skills, but those obtained in the countries of their origin often are not recognized. In another problem, even if they have the appropriate skills, employees are often inflexible and the cost of their transport and stay in a given country may be very high. Enterprises may not have adequate accommodation infrastructure for such workers, although they will often come to a given country on their own, look for a flat/accommodation, employment, etc. However, in such a case, it is more difficult to find an employee with appropriate qualifications [25].

Employment opportunities for people with disabilities are not taken into account in many enterprises. Often, this group of people are well educated, have appropriate skills, but are not employed due to their disabilities. Of course, their ability to perform a given job depends on the degree of their disabilities and the possibility of their adapting a given job to these disabilities. As a result, they are often locked at home, with no job opportunities, which unfortunately means professional exclusion for them. However, it is worth considering the issue of employing disabled employees in production enterprises, which could make production even more sustainable, precisely due to the elimination of the professional exclusion of disabled people and their possibility of being hired.

In many cases, people with disabilities are more inclined to work than non-disabled people, and often have the appropriate skills. However, the employers' lack of confidence in these skills means that they only choose non-disabled people. Sometimes it is enough to adjust the time and place of work appropriately to get a very valuable employee, who is no different from fully able-bodied people. Moreover, a disabled employee, due to difficulties in finding a new job, will stick to his employer, which may result in a change (decrease) in employee turnover.

Shaping safe and hygienic working conditions by the employer is a fundamental issue in the effective and qualitative performance of employee tasks. Therefore, there is no problem adapting these conditions also to people with disabilities. Recently, it was observed that the activation of people with physical and intellectual disabilities [26] and their employment in various types of enterprises, including production should be assessed very positively.

Performing professional duties is one of the basic activities that a person should engage in. It does not matter in the case of employees belonging to one of the groups with motor disabilities who, due to the occurrence of this disability, face additional difficulties in finding a well-paid job; their obstacles to finding a job not only focus on architectural barriers but also on the approach of society, including potential employers, to the employment of a disabled person [27]. Disabled people, as an important human factor, at the 
same time, are an important part of sustainable development and sustainable production. Glavič [10] indicated the twelve most cited megatrends (four social, four economic, and four environmental, in line with the areas of sustainable development). Among the social megatrends, the following should be noted:

- demographic and social changes (population growth, aging of the population; poverty, inequality, migration) with divergent global population trends (fertility, mortality) education and solidarity;

- $\quad$ health management and cost pressures, changing disease burden and pandemic riskshealthy living, public health systems, and intensive research;

- rapid urbanization (megacities, mobility, security) — smart: cities, communities and homes;

- regional instability (public debts, crises, economic and financial shocks, migrations, conflicts and wars, danger of collapse)—-more and more multi-circulation-new and intelligent world.

In these megatrends, there is an interest in people with disabilities. Additionally, according to the definition of sustainable development, one of the most important things contained in it is meeting the needs of all people, regardless of their status, social position, country of residence, or type of disability [28-30]. In order for people with disabilities to be full members of society, to live with dignity, and to meet their needs, they must be able to look after themselves (depending on the degree of disability, of course), and thus be able to find employment and earn a living.

Important research was carried out by Hussain and Jahanzaib [7] to identify important elements of individual areas of sustainable production. In the social area, they indicated:

- $\quad$ social needs and values;

- organization and social behavior;

- $\quad$ social performance, responsibility, reputation;

- $\quad$ social value, social benefits (local, national, global);

- $\quad$ social justice, standard of living, quality of life;

- health and safety, working conditions, employment opportunities, education and training, community welfare;

economic elements:

- $\quad$ socioeconomic trends;

- $\quad$ politics, business strategy, business model.

These elements can also be applied to people with disabilities and their employment in manufacturing companies.

As already mentioned, an important dimension of sustainable development is social sustainability, which is a life-enhancing condition within communities and a process within communities that can achieve that condition [31]. In Polish conditions, the social dimension of sustainable development must cover nine different areas. One of them includes a guarantee of social welfare for the elderly, the sick, and the disabled, ensuring a certain minimum subsistence level and the possibility of functioning in society [30].

The modern world poses more and more challenges for the functioning of individuals. The constantly increasing frequency of changes, largely caused by the rapid development of information technologies and automation, poses challenges in the field of mobility and forces an increasing pace of decision-making, i.e., an efficient response to these changes that affect the individual. To the average citizen, people with disabilities may seem, in some ways, beyond competition. Depending on the degree and type of disability, their ability to make decisions, mobility, and the speed of self-determination may be significantly limited. Does this mean that a disabled person has no chance of finding a "good" job? Do the characteristics of a disabled worker have to be less attractive compared to the characteristics of an ordinary employee? On the other hand, the companies have problems with crews. It is more and more difficult company goal to reduce employee turnover. In many developed countries, institutions co-finance the workplace of a disabled person. In Poland, according to the publicly available data of the State Fund for Rehabilitation 
of Disabled People (PFRON), this institution co-finances the workplace of a disabled person up to $90 \%$ in the case of social institutions and up to $75 \%$ in the case of employers conducting business activity [32]. On the other hand, the circles of people with disabilities provide information about problems with finding a job, and the need to pay attention to the expectations of employers with regard to the highest degree of disability, which determines the level of support provided by the state [33]. Is the work efficiency of a disabled person actually four times lower than that of an ordinary employee? Or maybe we are dealing with pathology consisting in extorting state funds and (indirect) feeding on disabled people?

\subsection{Purpose of the Article}

The authors, while working in enterprises providing consulting services, noticed that companies using the work of people with disabilities are generally not on the border of profitability, and often record (seemingly) satisfactory financial results. Are the costs of managing the work of people with disabilities so high or, perhaps, the so-called ablebodied employee accepts such a low salary that a disabled person, despite significant subsidies from the state, is still not very competitive? What factors have a key influence on the attractiveness of the perception of a specific job for a disabled person? The abovementioned questions prompted the authors to outline a research gap and start research on the above topic. This research is twofold. The first part was based on getting to know the opinion of the interested persons themselves, i.e., people with disabilities. The second part was to consult companies that employ people with disabilities. Each part will be performed with different tools and methods.

The purpose of the article is the desire to share information about results of scientific research that responds to the needs of the modern world, especially if it has significant social and business value. The input to the science is that there is an additional unused potential part of society (disabled people) that can be helpful in resolving current problems and also scientific ones. The science is able and should point to those ways of solving problems, which are in line with many groups of interests (stakeholders), for example, business and society.

Considerations on the above-mentioned aspects lead the authors to formulate the hypotheses that could be accepted or rejected during the research. The hypothesis named $\mathrm{HO}$ is to verify whether the key factor influencing the attractiveness of a given job for a disabled person depends on the type of disability they have. The hypothesis named H0a is to verify if persons with disabilities, after being hired for work, do not stay employed with the same employer for a longer period than "able-bodied" employees, i.e., there are no differences in the median (distribution) of employment time between disabled and non-disabled people. For the purposes of scientific research that (in this case) is expected to be compliant with the statistical testing process, the alternative hypotheses has been formulated. They are presented in the following section (see Materials and Methods).

\section{Materials and Methods}

Regarding the above-mentioned recognized research gap, the following research hypotheses have been outlined:

Hypothesis $\mathbf{0}(\mathbf{H 0 )}$. The key factor influencing the attractiveness of a given job for a disabled person depends on the type of disability they have (amenities should be particularly personalized).

\section{Alternative hypothesis to $\mathrm{Ho:}$}

Hypothesis 1 (H1). The factor that makes a job attractive for a disabled person does not depend on the type of disability (in other words: all disabled people expect similar benefits).

Hypothesis 0a (H0a). Persons with disabilities, after being hired for work, do not stay employed with the same employer for a longer period than the so-called "able-bodied" employees, i.e., there 
are no differences in the median (distribution) of employment time between disabled and nondisabled people.

\section{Alternative hypothesis to H0a:}

Hypothesis 1a (H1a). Persons with disabilities, after being hired, remain employed by the same employer for longer than the so-called "able-bodied" employees; in other words, there are differences in medians (schedules) of employment time between disabled people and non-disabled to the benefit of disabled people (the median for them is higher).

In order to verify the presented research hypotheses, a study was carried out on the cooperation of companies and people with disabilities under the employment relationship, using a questionnaire tool. A separate questionnaire was distributed among people with disabilities in order to better understand the opinions of the interested parties and the ability to verify compliance views (or recognition of discrepancies) between disabled people and their employers. Depending on the approach, the above can be called one study or two studies: main and follow-up, because different questionnaires were distributed.

In terms of materials and methods, the empirical part included the development and analysis of the results of the conducted quantitative and qualitative research, with the use of a questionnaire and direct (in-depth) interview. The questionnaire was used in the case of disabled persons, while the direct (in-depth) interview in the case of representatives of companies, which hire those disabled persons. The study was made with the use of the above-mentioned two research methods and two research tools.

The direct (in-depth) interview in the case of representatives of companies took the form of a casual conversation so as not to embarrass the respondents. On the other hand, the questionnaire for disabled persons was completed independently by the respondents and was in a paper form. Then the test results were saved in an Excel file.

The study took place from September to December 2020. The research was directed at manufacturing enterprises and the disabled people working there. In total, 141 disabled persons and 25 representatives of companies participated. The disabled persons were selected randomly from all the disabled staff hired in those 25 companies. The companies were not selected randomly-companies were chosen taking into consideration the factor of engaging disabled people in the companies' processes. Table 1 presents more detailed information about the disabled individuals and their numbers by each company.

Table 1. Characteristics of the disabled individuals-number of respondents by each company.

\begin{tabular}{cc}
\hline Number of Company & $\begin{array}{c}\text { Number of Disabled Respondents by Each } \\
\text { Company (Total = 141) }\end{array}$ \\
\hline 1 & 7 \\
\hline 2 & 8 \\
\hline 3 & 13 \\
\hline 4 & 11 \\
\hline 5 & 2 \\
\hline 6 & 7 \\
\hline 7 & 1 \\
\hline 8 & 10 \\
\hline 9 & 4 \\
\hline 10 & 18 \\
\hline 11 & 9 \\
\hline 12 & 3 \\
\hline
\end{tabular}


Table 1. Cont.

\begin{tabular}{cc}
\hline Number of Company & $\begin{array}{c}\text { Number of Disabled Respondents by Each } \\
\text { Company (Total = 141) }\end{array}$ \\
\hline 13 & 4 \\
\hline 14 & 9 \\
\hline 15 & 2 \\
\hline 16 & 7 \\
\hline 17 & 4 \\
\hline 18 & 1 \\
\hline 19 & 5 \\
\hline 20 & 3 \\
\hline 21 & 4 \\
\hline 22 & 2 \\
\hline 23 & 3 \\
\hline 24 & 3 \\
\hline 25 & 1 \\
\hline
\end{tabular}

Table 2 presents detailed information about the disabled individuals-number of respondents by gender.

Table 2. Characteristics of the disabled individuals—number of respondents by gender.

\begin{tabular}{cc}
\hline Gender & Number of Individuals (of 141 Respondents) \\
\hline Males & 80 \\
\hline Females & 61 \\
\hline
\end{tabular}

Table 3 presents detailed information about the disabled individuals-number of respondents by age.

Table 3. Characteristics of the disabled individuals—number of respondents by age.

\begin{tabular}{cc}
\hline Age & Number of Individuals (of 141 Respondents) \\
\hline $18-25$ y.o. & 10 \\
\hline $26-30$ y.o. & 24 \\
\hline $31-35$ y.o. & 31 \\
\hline $36-40$ y.o. & 25 \\
\hline $41-45$ y.o. & 15 \\
\hline $46-50$ y.o. & 35 \\
\hline Older than 50 & 1 \\
\hline
\end{tabular}

Table 4 presents detailed information about the disabled individuals-number of respondents by work experience. 
Table 4. Characteristics of the disabled individuals-number of respondents by work experience.

\begin{tabular}{cc}
\hline Working Experience (Years in Service) & Number of Individuals (of 141 Respondents) \\
\hline Less than 5 YEX & 17 \\
\hline $6-10$ YEX & 29 \\
\hline $11-15$ YEX & 28 \\
\hline $16-20$ YEX & 22 \\
\hline $21-25$ YEX & 17 \\
\hline $26-30$ YEX & 27 \\
\hline More than 30 YEX & 1 \\
\hline
\end{tabular}

These were pilot studies. Their purpose was to check the correctness of the selection of questions in the case of both research methods. Additionally, it was checked how the survey was perceived by both groups of respondents. We wanted to deepen the knowledge of the problem under study, which will allow for the refinement of research methods. After analyzing the results of the pilot studies and improving the research methods, appropriate studies were carried out on a non-representative research group (minimum 300 enterprises and 2000 disabled people).

The collected data was processed using the statistical tests presented below, aimed at the optimal analysis of empirical data constituting the foundation for a solution to the assessment of the effectiveness of the application of characteristic processes in managing the work of disabled people in enterprises. Two statistical tests were used in the analysis: the Mann-Whitney exact test (good for small groups) and the asymptotic test (more appropriate for more numerous groups). These are the variants of the U Mann-Whitney non-parametric test for independent samples.

The tables below present the questions contained in both of the questionnaires. In Table 5, the version for the enterprises was presented. The explanation of the importance and meaning of the questions presented below to the scientific process is described in the last column.

In Table 6 the version for the disabled persons was presented. The answers were given anonymous. 
Table 5. Questions asked to the representative of the companies, which employ disabled persons.

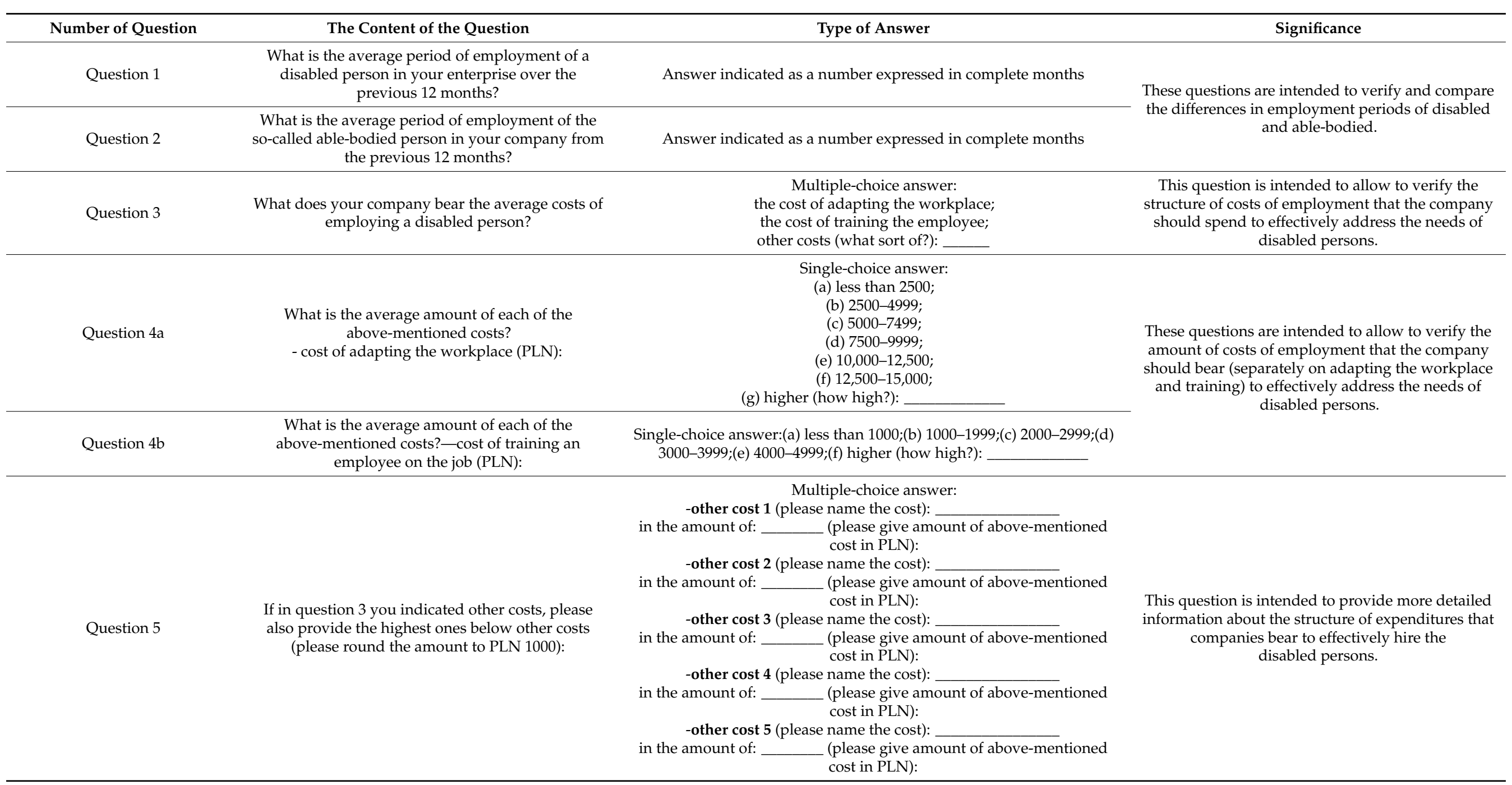


Table 5. Cont.

\section{Number of Question}

Question 6 yes to the above question, which of

Question 7 such

In your opinion, can any of the above-mentioned

costs of employing a disabled person be reduced

when recruiting another disabled person for the same position in the future?

(This may occur case, for example, when the

adaptation of the workplace or the training

materials are suitable for use by other disabled employees in the future)

Type of Answer

Significance

\begin{tabular}{ccc}
\hline Question 7 & $\begin{array}{c}\text { If you answered yes to the above question, which of } \\
\text { the above-mentioned costs can be indicated as } \\
\text { such costs? }\end{array}$ & Free written expression \\
Question 8 & $\begin{array}{c}\text { If you answered no to question 6, or you chose the } \\
\text { answer c), pleaseindicate why? }\end{array}$ & Fritten expression \\
Question 9 & $\begin{array}{c}\text { How, in your opinion, is the productivity of a } \\
\text { disabled person (after incurring the above costs) } \\
\text { compared to able-bodied workers? }(-90 \text { means } \\
\text { about } 90 \% \text { less work efficiency, }+90 \text { means about } \\
90 \% \text { more work efficiency) }\end{array}$ & $\begin{array}{c}\text { Single-choice answer: } \\
\text { (a) production } \\
\text { (b) services }\end{array}$ \\
\hline Question 10 & (c) both of above \\
\hline
\end{tabular}

Question 11

How long is the company present on the market?

Answer indicated as a number expressed in complete years

Question 12

How many employees your company employs?

Answer indicated as a number

This question is intended to provide the information about the possibility of optimization of

company expenditures on hiring disabled.

This question is intended to provide more detailed information about the way to optimize the company expenditures on hiring disabled.

This question is intended to provide more detailed information to understand why the company costs of hiring disabled persons are hard or impossible to

$$
\text { be optimized. }
$$

This question is intended to provide the information about the effectiveness of above-listed company expenditures on hiring disabled persons on their work productivity.

It is expected that the answers may vary depending on the area (industry). This question is intended to verify the areas with higher opportunities to hire disabled effectively (where they can really compare with able-bodied persons) and where the cost of their employment can be more easily optimized.

It is expected that the answers may vary depending on the time the company is present on the market. This question is intended to verify the differentiation taking under consideration the factor of time of presence on the market.

It is expected that the answers may vary depending on the size of the company. This question is intended to verify the differentiation taking under consideration this factor. 
Table 6. Questions asked to the disabled persons.

\begin{tabular}{|c|c|c|c|}
\hline Number of Question & The Content of the Question & Type of Answer & Significance \\
\hline Question 1 & $\begin{array}{l}\text { Which of the following factors are the most } \\
\text { important in your case when choosing a job? }\end{array}$ & $\begin{array}{c}\text { Single-choice answer: } \\
\text { (a) preparation of the workplace strictly taking into } \\
\text { account my disability; } \\
\text { (b) the possibility of flexible selection of remote work; } \\
\text { (c) the ability to perform } 100 \% \text { of entrusted tasks } \\
\text { from home; } \\
\text { (d) availability of a dedicated person to help people } \\
\text { with disabilities in the company; } \\
\text { (e) other factor (what?): ....................... }\end{array}$ & $\begin{array}{c}\text { This question is intended to distinguish the mos } \\
\text { important factors (when choosing the job) for } \\
\text { disabled persons. }\end{array}$ \\
\hline Question 2 & $\begin{array}{l}\text { How long have you been employed by one } \\
\text { employer for the longest time? }\end{array}$ & $\begin{array}{l}\text { Answer indicated as a number expressed in } \\
\text { complete months }\end{array}$ & $\begin{array}{l}\text { The answers for these questions may let to } \\
\text { compare the average time of employment } \\
\text { declared by the disabled people and declared by } \\
\text { employers (presented in the previous Table) }\end{array}$ \\
\hline Question 3 & $\begin{array}{l}\text { Please describe what, in your opinion, has a } \\
\text { key impact on the situation in a given place } \\
\text { (company), where you work well and you do } \\
\text { not want to change job position: }\end{array}$ & Free written expression & $\begin{array}{l}\text { This question is intended to distinguish the mos } \\
\text { important aspects (for disabled persons) requirec } \\
\text { to long term satisfaction about their job }\end{array}$ \\
\hline Question 5 & $\begin{array}{c}\text { Do you know the indicative costs that your } \\
\text { employer has incurred to make it possible to } \\
\text { offer a job to you? }\end{array}$ & $\begin{array}{l}\text { Single-choice answer: } \\
\text { (a) yes, it was the amount of approximately (please } \\
\text { round to the nearest thousand PLN): } \\
\text { (b) I don't know. }\end{array}$ & $\begin{array}{l}\text { This question is intended to analyze and verify it } \\
\text { disabled persons are aware of the scope of } \\
\text { expenditures made of their workplace. }\end{array}$ \\
\hline Question 6 & $\begin{array}{l}\text { Do you think that the employer's incurrence } \\
\text { of these costs in any way makes in the future, } \\
\text { will it be easier for you to find another job? }\end{array}$ & $\begin{array}{l}\text { Single-choice answer with one filled-in sentence: } \\
\text { (a) yes, because: } \\
\text { (b) no. }\end{array}$ & $\begin{array}{l}\text { This question is intended to analyze and verify } \\
\text { the long-term impact of expenditures on the } \\
\text { workplace for disabled people. }\end{array}$ \\
\hline Question 7 & $\begin{array}{l}\text { How do you rate your own performance at } \\
\text { your job compared to the so-called } \\
\text { able-bodied workers? } \\
\text { (-90 means about } 90 \% \text { less work efficiency, } \\
+90 \text { means about } 90 \% \text { more work efficiency) }\end{array}$ & A number between -90 to +90 . & $\begin{array}{l}\text { This question is intended to get to know and } \\
\text { analyze the self-opinion of disabled persons abou } \\
\text { the performance of their own work. }\end{array}$ \\
\hline
\end{tabular}


Table 6. Cont.

\begin{tabular}{|c|c|c|c|}
\hline Number of Question & The Content of the Question & Type of Answer & Significance \\
\hline Question 8 & What is your gender? & $\begin{array}{l}\text { Single-choice answer: } \\
\text { (a) female } \\
\text { (b) male }\end{array}$ & $\begin{array}{l}\text { It is expected that the answers may vary } \\
\text { depending on the sex of the respondent. This } \\
\text { question is intended to distinguish it. }\end{array}$ \\
\hline Question 9 & What is your age? & $\begin{array}{l}\text { Answer indicated as a number expressed in } \\
\text { complete years }\end{array}$ & $\begin{array}{l}\text { It is expected that the answers may vary } \\
\text { depending on the age of the respondent. This } \\
\text { question is intended to distinguish it. }\end{array}$ \\
\hline Question 10 & What is your occupation? & Answer expressed as one filled-in sentence: & $\begin{array}{l}\text { It is expected that the answers may vary } \\
\text { depending on the occupation of the respondent. } \\
\text { This question is intended to distinguish it. }\end{array}$ \\
\hline Question 11 & $\begin{array}{l}\text { Could you be so kind and point out what is } \\
\text { your disability? }\end{array}$ & Answer expressed as one filled-in sentence: & $\begin{array}{l}\text { It is expected that the answers may vary } \\
\text { depending on the sort of disability of the } \\
\text { respondent. This question is intended to } \\
\text { distinguish it. }\end{array}$ \\
\hline Question 12 & Where do you live? & $\begin{array}{l}\text { Single-choice answer: } \\
\text { (a) Countryside } \\
\text { (b) City up to } 50,000 \text { residents } \\
\text { (c) City } 51-100 \text { thousand residents } \\
\text { (d) City } 101-500 \text { thousand residents } \\
\text { (e) City over } 500,000 \text { residents }\end{array}$ & $\begin{array}{l}\text { It is expected that the answers may vary } \\
\text { depending on the place of living of the } \\
\text { respondent. This question is intended to } \\
\text { distinguish it. }\end{array}$ \\
\hline
\end{tabular}




\section{Results and Discussion}

In order to verify the H0a hypothesis that people with disabilities, after being hired for work, do not stay employed with the same employer for a longer period than the socalled "able-bodied" employees, i.e., there are no differences in the median (distribution) of employment time between disabled and non-disabled people, data was collected through questions 1 and 2 of questionnaire 1 , as presented in Table 5, concerning the average periods of employment of disabled and non-disabled people in companies.

The collected data (Table 7 and Figure 1) indicate that among the surveyed people, the highest percentage were people with motor disabilities (36.88\%). People with other disabilities: intellectual, sight, and hearing/speech disabilities accounted for 15.60, 24.82, and $22.70 \%$, respectively. The most frequently indicated factors encouraging to take up work were that it is possible to perform $100 \%$ of entrusted tasks from home and individual preparation of the workplace - an equal $31.91 \%$ of indications for each. Factors were: availability of a person dedicated to help people with disabilities in the company and the possibility of flexible selection of remote work were indicated in 19.86 and $16.31 \%$ of cases, respectively. In Figure 1, the collected data in graphical form is presented.

Table 7. The most important factor influencing the attractiveness of a given job for a disabled person (according to respondents with disabilities).

\begin{tabular}{ccccc}
\hline & $\begin{array}{c}\text { Individual } \\
\text { Preparation of the } \\
\text { Workplace in Terms of } \\
\text { the Disability of a } \\
\text { Specific Person }\end{array}$ & $\begin{array}{c}\text { Possibility of } \\
\text { Flexible Selection of } \\
\text { Remote Work }\end{array}$ & $\begin{array}{c}\text { Possibility to } \\
\text { Perform 100\% of } \\
\text { Entrusted Tasks } \\
\text { from Home }\end{array}$ & $\begin{array}{c}\text { Availability in the } \\
\text { Company of a } \\
\text { Dedicated Person to } \\
\text { Help People with } \\
\text { Disabilities }\end{array}$ \\
\hline Motor disability & 27 & 7 & 9 & 9 \\
\hline Intellectual disability & 5 & 5 & 5 & 7 \\
\hline Visual impairment & 8 & 5 & 17 & 5 \\
\hline Hearing/speech disability & 5 & 6 & 14 & 7 \\
\hline
\end{tabular}



- Availability in the company of a dedicated person to help people with disabilities

Possibility to perform $100 \%$ of entrusted tasks from home

- Possibility of flexible selection of remote work

- Individual preparation of the workplace in terms of the disability of a specific person

Figure 1. The collected data presented in a graphical form.

The calculations were made using the Statistica program [34]. As a result of the calculations, the following was determined:

- $\quad$ the number of degrees of freedom equal to 9;

- $\quad$ significance level of $\mathrm{p}=0.007$.

Subsequently, the value of $\chi^{2}$ was calculated with 9 degrees of freedom, this value was -22.55705 . The fi Yule index confirmed the presence of a high strength of the relation- 
ship between the analyzed features, as it was 0.399974 . The equation of fi Yule index is presented below.

$$
Q=\frac{a d-b c}{a d+b c}
$$

The obtained result is statistically significant because the probability of rejecting the hypothesis is lower than 0.05 [35]. The H0 hypothesis has been accepted; the key factor influencing the attractiveness of a given job for a disabled person depends on the type of disability they have.

Thus, the H1 hypothesis about the independence of the factor when choosing a job position in terms of the type of disability was rejected. None of the values in Table 7 are less than 5 , therefore, it is not necessary to make a Yates correction.

In order to verify the hypothesis H0a that people with disabilities upon admission to work are not employed by the same employer longer than the so-called "able-bodied" employees, i.e., there are no differences in the median (distribution) of employment time between disabled and non-disabled people, data was collected through questions 1 and 2 of the questionnaire 1 , as presented in Table 5 , is the version for the companies, concerning the average periods of employment of disabled and non-disabled people in companies.

To verify the H0a hypothesis, a non-parametric $U$ Mann-Whitney test was performed. This test verifies the null hypothesis that two randomly selected samples are from the same population. The equation of $U$ Mann-Whitney test is presented below.

$$
U=N M+\frac{N(N+1)}{2}-\sum_{x_{i}} \operatorname{Rank}\left(x_{i}\right)
$$

The set of data that was subjected to the test includes: an independent variable (grouping - the fact of confirmed disability) and a dependent variable (length of employment expressed in months), which was measured on a quantitative scale. This data wascollected thanks to the answers of the respondents to questions 1 and 2 (first and second) in the questionnaire 1 -the enterprise version fragment presented above in Table 5. The PQStat Software [36] was used to carry out statistical tests. The continuity adjustment option was used to ensure that the statistic test assumes all real numbers under the assumption of the normal distribution. In this way, the test was performed in a more conservative (stringent) manner. The above correction applies to the asymptotic test. Two tests were used in the analysis: the Mann-Whitney exact test (good for small groups) and the asymptotic test (more appropriate for more numerous groups) [37].

- The significance level of the analysis is 0.05 ;

- The median time of employment for people with disabilities was 24 months;

- The median time employed for non-disabled people was 18 months;

- The exact p (two-tailed) test was 0.040588;

- The asymptotic (two-sided) p test was 0.041307 .

The asymptotic test included two fixes: a continuity correction and a tied rank correction. This adjustment has to be taken into account as there are tied ranks in this case, i.e., the values in the data sample are repeated (e.g., the number of 24 months occurs 3 times).

The value of the $\mathrm{Z}$ statistic with the correction for tied ranks was 2.040437 .

Figure 2 presents the comparison of medians, quartiles, and cut-offs for employment periods of disabled and able-bodied workers, while Figure 3 presents the comparison of the number of samples for specific periods of employment of disabled (n) and able-bodied (p) workers. 




Figure 2. Comparison of medians, quartiles and cut-offs for employment periods disabled (n) and able-bodied (p) workers.

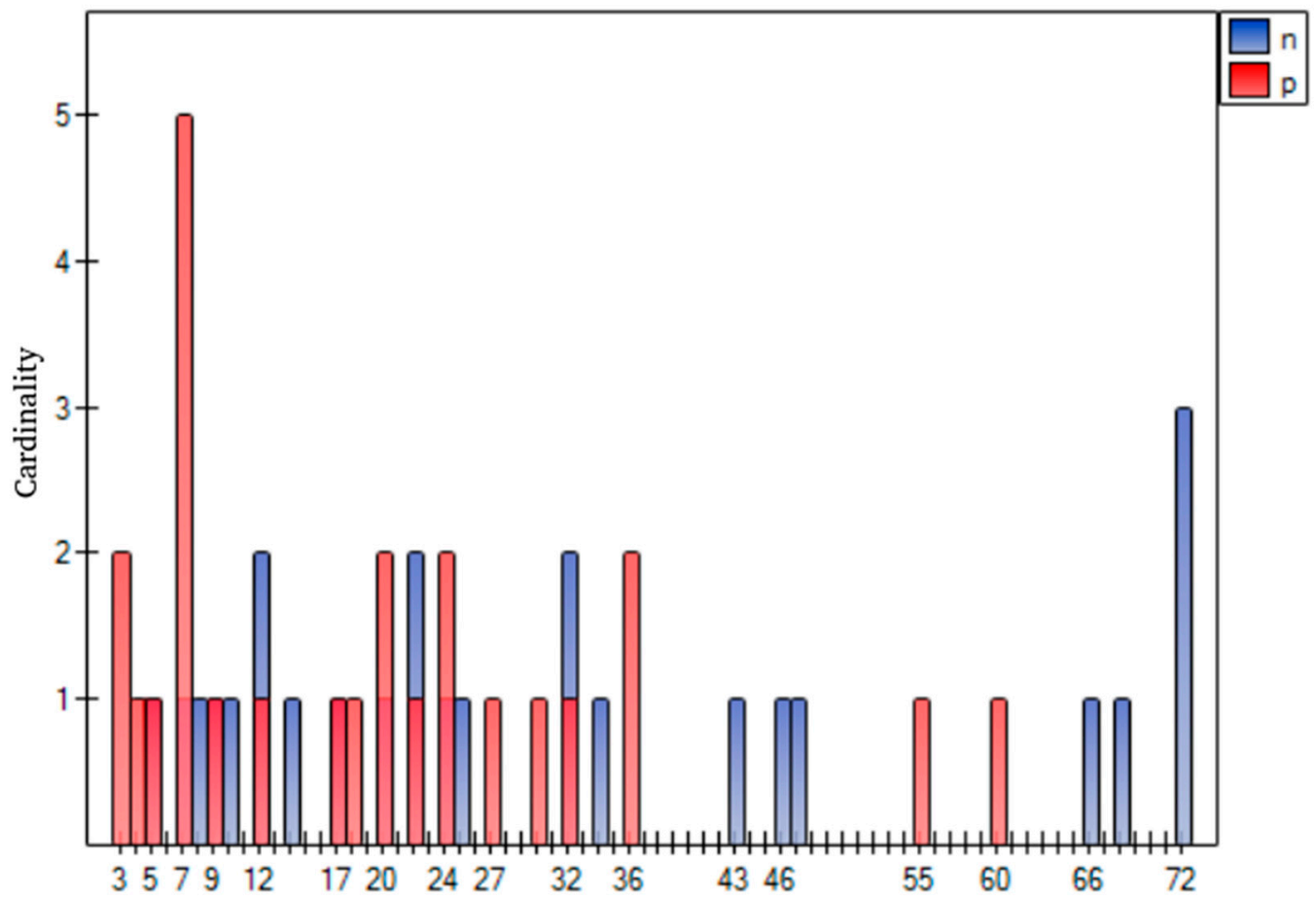

Figure 3. Comparison of the number of samples for specific periods of employment of disabled (n) and "able-bodied" (p) workers-the transparency effect was used in the graph.

Hypothesis 0a (H0a). People with disabilities, after being hired for work, do not stay employed with the same employer longer than "able-bodied" employees, i.e., there are no differences in the median (distribution) of employment time between disabled and non-disabled people.

Alternative hypothesis to HOa: 
Hypothesis 1a (H1a). Persons with disabilities, after being accepted for work, remain employed by the same employer longer than the so-called 'Able-bodied' workers, in other words: there are differences in the median (distribution) of employment time between disabled and non-disabled persons.

Since the values of the p-test are below the cut-off value of 0.05 , we consider the hypothesis H0a as invalid (rejected) and accept the hypothesis H1a. After being hired, disabled people stay employed with the same employer longer than the so-called "ablebodied" employees, in other words, there are differences in the median (distribution) of employment time between persons disabled and able-bodied.

Finally, it is highly probable that there is a correlation between the amount of costs incurred to adapt the workplace of a disabled person and the effectiveness of this person's work. The times when a constant trend of the decreasing cost of access to technology and information is observed, it will surely bring changes in the form of cheaper ways of adapting the workplace in such an effective way that employing a disabled person in a given position will not, in any way, reduce the work efficiency obtained from this position. In the foreseeable, rational future, the employer will pay off to obtain a prosthesis for a disabled person, the exoskeleton or a machine that automates this person movements (for example, a bionic arm), just as it is now profitable to obtain a computer, electric tools or a means of transportation. It is worth considering now (for example, investigating, trying to prove scientifically) whether a loyal and permanent employee is worth such investment today.

\section{Conclusions}

Interesting conclusions can be drawn when summarizing the research on employing disabled people in Polish enterprises. Firstly, the research proved that the key factor influencing the attractiveness of a given job for a disabled person depends on the type of disability. In terms of tested hypotheses, the H0 hypothesis has been accepted, which means the key factor influencing the attractiveness of a given job for a disabled person depends on the type of disability they have.

Secondly, after being hired, people with disabilities remain employed by the same employer longer than the so-called "able-bodied" employees, in other words, there are differences in the median (distribution) of employment time between disabled and nondisabled people. Therefore, the hypothesis H1a is considered as valid (it was accepted). It means that after being hired, disabled people stay employed with the same employer longer than the so-called "able-bodied" employees.

Finally, the presented research considers the employment of people with disabilities, as well as the impact of this process on sustainable production. It can be treated as a starting point for broader research on this topic. It should be noted that disabled people are full members of society and want to take an active part in social and economic life, and earn money for their living. This is the reason that the subject considered in this article should be publicized, and its positive aspects should be shown. Further, a more detailed look at the costs of employing a disabled employee, together with the analysis of the employment time of such an employee, may shed an interesting light on the profitability of employing people with disabilities. It is important to emphasize that further research is needed.

The following could be limitations of this research. First, the presented research results relate only to preliminary research. Their aim was to check the questions used in both research methods to eliminate potential errors. Additionally, it was assumed from the beginning that the sample would be unrepresentative. It should be remembered that the research took two forms: a questionnaire in the case of disabled persons and direct (in-depth) interviews in the case of representatives of companies. In the case of both research methods, a predetermined list of questions was used, which were developed on the basis of the experience of the authors and previous literature research, which affects the possibility of burdening the questions with the subjectivity of the authors. Additionally, the authors had no influence on how the disabled people responded, because they themselves 
answered the questions, and in case of misunderstanding the question, they could not ask the researchers for help. As for the face-to-face interview, the researchers could to some extent influence the responses, as at some points, it was supposed to take the form of free discussion.

Author Contributions: Conceptualization, T.C.; methodology, T.C.; formal analysis, T.C.; writingoriginal draft preparation, T.C.; writing-review and editing, M.I.; supervision, M.I. Both authors have read and agreed to the published version of the manuscript.

Funding: Publication financed from statutory research of the Czestochowa University of Technology SPB-600-3016/2021.

Institutional Review Board Statement: Not applicable.

Informed Consent Statement: Not applicable.

Conflicts of Interest: The authors declare no conflict of interest.

\section{References}

1. Pagotto, E.L.; Gonçalves-Dias, S.L.F. Sustainable consumption and production from a strategic action field perspective. Ambiente Soc. 2020, 23, e00271. [CrossRef]

2. Bolis, I.; Morioka, S.N.; Sznelwar, L.I. When sustainable development risks losing its meaning. Delimiting the concept with a comprehensive literature review and a conceptual model. J. Clean. Prod. 2014, 83, 7-20. [CrossRef]

3. Perey, R. Making sense of sustainability through an individual interview narrative. J. Cult. Organ. 2015, 21, 147-173. [CrossRef]

4. Wiśniewska-Sałek, A. Managing a Sustainable Supply Chain-Statistical Analysis of Natural Resources in the Furniture Industry. Manag. Syst. Prod. Eng. 2021, 29, 227-234. [CrossRef]

5. Vevela, V.; Ellenbecker, M. Indicators of sustainable production: Framework and methodology. J. Clean. Prod. 2001, 9, 519-549. [CrossRef]

6. Hashim, M.; Nazam, M.; Abrar, M.; Hussain, Z.; Nazim, M.; Rizwan Shabbir, R. Unlocking the Sustainable Production Indicators: A Novel TESCO based Fuzzy AHP Approach. Cogent Bus. Manag. 2021, 8, 1870807. [CrossRef]

7. Hussain, S.; Jahanzaib, M. Sustainable manufacturing-An overview and a conceptual framework for continuous transformation and competitiveness. Adv. Prod. Eng. Manag. 2018, 13, 237-253. [CrossRef]

8. Wolf, M.A.; Chomkhamsri, K. From Sustainable Production to Sustainable Consumption. In LCA Compendium-The Complete World of Life Cycle Assessment; Sonnemann, G., Margni, M., Eds.; Life Cycle Management; Springer: Dordrecht, The Netherlands, 2015. [CrossRef]

9. United Nations Industrial Development Organization. Green Industry for a Low Carbon Future. Available online: http: //www.unido.org/greenindustry/green-industry-initiative.html (accessed on 29 August 2021).

10. Glavič, P. Evolution and Current Challenges of Sustainable Consumption and Production. Sustainability 2021, 13, 9379. [CrossRef]

11. Ulewicz, R.; Kleszcz, D.; Ulewicz, M. Implementation of Lean Instruments in Ceramics Industries. Manag. Syst. Prod. Eng. 2021, 29, 203-207. [CrossRef]

12. Wolniak, R. The concept of operation and production control. Prod. Eng. Arch. 2021, 27, 100-107. [CrossRef]

13. Szymanski, P.; Zolnieruk, M.; Oleszczyk, P.; Gisterek, I.; Kajdanowicz, T. Spatio-Temporal Profiling of Public Transport Delays Based on Large-Scale Vehicle Positioning Data From GPS in Wroclaw. IEEE Trans. Intell. Transp. Syst. 2018, 19, 3652-3661. [CrossRef]

14. Baryshnikova, N.; Kiriliuk, O.; Klimecka-Tatar, D. Management approach on food export expansion in the conditions of limited internal demand. Pol. J. Manag. Stud. 2020, 21, 101-114. [CrossRef]

15. Klimecka-Tatar, D. Analysis and improvement of business processes management-Based on value stream mapping (VSM) in manufacturing companies. Pol. J. Manag. Stud. 2021, 23, 213-231. [CrossRef]

16. Knop, K. Analysing the machines working time utilization for improvement purposes. Prod. Eng. Arch. 2021, 27, 137-147. [CrossRef]

17. Kardas, E.; Brožova, S.; Pustějovská, P.; Jursová, S. The Evaluation of Efficiency of the Use of Machine Working Time in the Industrial Company-Case Study. Manag. Syst. Prod. Eng. 2017, 25, 241-245. [CrossRef]

18. Smirnova, E.; Kot, S.; Kolpak, E.; Shestak, V. Governmental support and renewable energy production: A cross-country review. Energy 2021, 230, 120903. [CrossRef]

19. Brendzel-Skowera, K. Circular Economy Business Models in the SME Sector. Sustainability 2021, 13, 7059. [CrossRef]

20. Karcz, J.; Ślusarczyk, B. Criteria of quality requirements deciding on choice of the logistic operator from a perspective of his customer and the end recipient of goods. Prod. Eng. Arch. 2021, 27, 58-68. [CrossRef]

21. Czajkowska, A.; Ingaldi, M. Application of Servqual and Servperf Methods to Assess the Quality of Teaching ServicesComparative Analysis. Manuf. Technol. 2021, 21, 294-305. [CrossRef]

22. Kadłubek, M.; Grabara, J. Customers' expectations and experiences within chosen aspects of logistic customer service quality. Int. J. Qual. Res. 2015, 9, 265-278. 
23. Klimecka-Tatar, D.; Nieciejewska, M. Small-sized enterprises management in the aspect of organizational culture. Rev. Gest. Tecnol.-J. Manag. Technol. 2021, 21, 4-24. [CrossRef]

24. Lepold, A.; Tanzer, N.; Bregenzer, A.; Jiménez, P. The Efficient Measurement of Job Satisfaction: Facet-Items versus Facet Scales. Int. J. Environ. Res. Public Health 2018, 15, 1362. [CrossRef]

25. Ingaldi, M.; Ulewicz, R. Problems with the Implementation of Industry 4.0 in Enterprises from the SME Sector. Sustainability 2020, 12, 217. [CrossRef]

26. Niciejewska, M. Occupational health and safety management in terms of special employee needs-Case study. Syst. Saf. Hum.-Tech. Facil.-Environ. 2021, 3, 55-63. [CrossRef]

27. Tkacz, M. The Professional Situation Od Disabled People on the Bieszczady Poviat. Syst. Saf. Hum.-Tech. Facil.-Environ. 2021, 3, 245-252. [CrossRef]

28. Blanck, P.; Adya, M.; Myhill, W.N.; Samant, D.; Chen, P. Employment of people with disabilities-Twenty-five years back and ahead. Minn. J. Law Inequal. 2007, 25, 323-353.

29. Caulfield, J.L. Measuring autonomy in social security agencies: A four country comparison. Public Adm. Dev. SI Symp. Auton. Organ. Public Sect. 2004, 24, 137-145. [CrossRef]

30. Wolniak, R.; Skotnicka-Zasadzień, B. Developing a Model of Factors Influencing the Quality of Service for Disabled Customers in the Condition s of Sustainable Development, Illustrated by an Example of the Silesian Voivodeship Public Administration. Sustainability 2018, 10, 2171. [CrossRef]

31. McKenzie, S. Social Sustainability: Towards Some Definitions; University of South Australia: Adelaide, Australia, 2004.

32. Wysokość Dofinansowania do Wynagrodzeń Pracowników Niepełnosprawnych, Państwowy-Fundusz Rehabilitacji Osób Niepełnosprawnych. Available online: https://www.pfron.org.pl/pracodawcy/dofinansowanie-wynagrodzen/wysokoscdofinansowania-do-wynagrodzen-pracownikow-niepelnosprawnych/ (accessed on 1 March 2021).

33. Rebernik, N.; Szajczyk, M.; Bahillo, A.; Goličnik Marušić, B. Measuring disability inclusion performance in cities using Disability Inclusion Evaluation Tool (DIE Tool). Sustainability 2020, 12, 1378. [CrossRef]

34. STATSOFT. Available online: https://www.statsoft.pl/Pelna-lista-programow-Statistica/?goto=statistica_enterprise\#sc (accessed on 20 January 2021).

35. Herdan, G. The mathematical relation between Greenberg's index of linguistic diversity and Yule's characteristic. Biometrika 1958, 45, 268-270. [CrossRef]

36. PQStat Software. Available online: https:/ / pqstat.pl/?mod_f=usersm (accessed on 20 January 2021).

37. Nachar, N. The Mann-Whitney U: A test for assessing whether two independent samples come from the same distribution. Tutor. Quant. Methods Psychol. 2008, 4, 13-20. [CrossRef] 